\title{
Britain leads bid to cut costs of Europe's space science projects
}

Paris. Having successfully helped to engineer a major reduction in planned expenditure by the European Particle Physics Laboratory on its Large Hadron Collider (see opposite), Britain is now on a collision course with the European Space Agency (ESA) over the future funding of European space science missions.

At stake is the level of support for the various projects included under ESA's Horizon 2000 programme, a series of missions that started at the beginning of the decade and are already being planned into the first years of the next century.

Last week, Roger Bonnet, the head of ESA's science programme, warned that ESA may have to postpone or cancel some of these missions if the United Kingdom insists on a reduction in the programme's overall costs. He was speaking after ESA's council had failed to agree on proposed future funding levels for the programme.

British officials say their main concern is to increase the cost-effectiveness with which the $£ 37$ million (US\$58 million) Britain pays each year towards ESA's space science programmes is used.

But Bonnet, who is not prone to making rash public statements, claims that Britain wants a " 20 to 50 per cent" cut in funding of space science over the long term, and that this will inevitably lead to programme cuts.

According to Bonnet, the dispute takes place against a background of widespread

political apathy towards space activities among European countries. As a result, he warns that ESA is "in crisis", and that, in the absence of renewed political commitment, the long-term future of the agency itself is under threat.

Indeed, Bonnet suggests that the agenda of an interministerial meeting in 1995 should be enlarged into a full-blown European space conference to review the whole of space policy in the light of economic and political changes. "We need a new political commitment to space that is now lacking," says Bonnet.

One factor in the

\section{IMAGE \\ UNAVAILABLE FOR COPYRIGHT REASONS}

Bonnet: seeking to defend programme. success of Horizon 2000 is the funding stability it enjoys. Whereas ESA's 14 member states can choose whether to take part in the agency's technology programmes, such as the development of the Ariane launcher, they are obliged to contribute a fixed proportion of their gross national product to the space science programme, and future funding levels are agreed for five-year periods.

But simmering tensions, triggered partly by budget pressures in the United Kingdom, boiled over at a meeting in Paris last week of

\section{Australia hails a prehistoric pine}

\author{
Sydney. Not the world's smallest Christ- \\ mas tree, but - for those still seeking \\ unusual Christmas presents - perhaps \\ one of its first prehistoric pot plants. A \\ research officer at the Mount Annan \\ Botanic Gardens in Sydney, Australia, \\ holds the first seedling (right) raised from \\ a new species of pine, thought to have \\ been extinct for $\mathbf{1 5 0}$ million years, which \\ was discovered in a national park 125 \\ miles west of the city in August. \\ The discovery was halled in Australia \\ last week as one of the most important \\ finds of the century, equivalent, according \\ to Carrick Chambers, the director of the \\ gardens, to "finding a small dinosaur still \\ alive on Earth". \\ The pine was discovered by a project \\ officer with Australia's National Parks and \\ Wildlife Service when he abseiled into a \\ 1,800-foot deep gorge during a weekend \\ bush walk. In all, 42 trees were discov- \\ ered at a location that is not being \\ revealed. (see also page 719 )
}

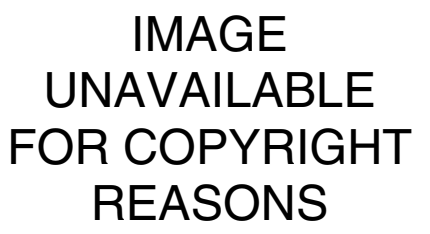

the ESA council, which is made up of representatives of each of the agency's member states. The meeting failed to vote on the level of funding for the period 19962000 after it emerged that the United Kingdom, Germany and Spain would oppose the figures proposed by the agency, based on increases at the rate of inflation. (Under ESA procedures, approval must be unanimous.)

The three countries had voted earlier in the meeting against the 1995 budget, arguing that this should be held to constant money, rather than growing at the anticipated rate of inflation. But the budget increase was still adopted, as it had already been agreed in principle under the current five-year plan, and therefore needed only majority approval. (Italy abstained from the vote, pending a review of its domestic national budget; see page 719.)

British officials have been quick to reject Bonnet's claims. "We are not seeking a reduced science programme," says Ian Corbett, director of science at the UK Particle Physics and Astronomy Research Council (PPARC), and the British representative on the ESA council.

But Corbett argues that ESA could cut 25 per cent of the costs of its science missions within five years, without reducing their scientific value, by making them more cost effective. He admits that Bonnet has a wellmanaged programme; "we're giving him 9 out of 10 ", says Corbett. "But saying that, you still have a bit to go."

PPARC's current difficulties stem from the fact that its budget for space science is being held level, while its subscription to ESA is increasing, leaving it with "less and less money" to spend on instruments or on exploiting the results of missions.

Bonnet says that he appreciates PPARC's problems, and is willing to seek ways to cut costs further, for example through the way contracts are shared among companies in the member states. Indeed an audit of the science programme, and ESA's general running costs, is already being carried out.

But he refuses to make cuts that could jeopardize the overall space science programme, and fears that Britain is looking on savings "as simply a means to reduce costs", rather than "as a way to do more science for the same money".

The question of how much funding Horizon 2000 will receive in its next five-year funding period will be considered by the space ministers of ESA member states at a meeting next autumn, which is also scheduled to decide on Europe's contribution to the planned international space station.

Declan Butler 